\title{
SUSCEPTIBILITY OF TERRAIN UNITS TO DUST DEFLATION AT RAS AZ-ZOR AREA, SOUTHERN KUWAIT
}

\begin{abstract}
A. Al-Hurban*, R. Misak**, A. Al-Ostad***

ABSTRACT

Under the environmental conditions of Kuwait, dust deflation is a function of climate, soil characteristics, moisture content, vegetation cover, and land use. Terrain units respond to these factors in different ways. These factors being ranked according to their influence on dust deflation into three major categories; high, moderate and slight effective. The main aim of this study is to determine the susceptibility of different terrain units to dust deflation at Ras Az-Zor area in southern part of Kuwait. Different major landforms were selected to this study such as smooth and rugged vegetated sand sheets, inland and coastal sabkhas, sand dunes, and oolitic ridges. Inland sabkhas is the most susceptible terrain to dust deflation (most erodible) followed by and smooth sand sheets, sand dunes, rugged vegetated sand sheets, then oolitic ridges. Coastal sabkhas are considered as the least unit to dust deflation (least erodible).
\end{abstract}

KEY WORDS: Deflation; Terrain units; Sabkhas; Susceptible; Sand sheet.

* Kuwait University.

** Kuwait Institute for Scientific Research.

*** Ministry of Education. 


\section{Introduction:}

The study area is situated in the southeastern part of Kuwait between latitudes $28^{\circ} 42^{\prime}$ and $28^{\circ} 49^{\prime}$ north and longitudes $48^{\circ} 12^{\prime}$ and $48^{\circ} 28^{\prime}$ east (Fig. 1). It covers an area of $451.77 \mathrm{~km}^{2}$. During March 2000, preliminary field investigations were held to examine the different landforms found in the study area. Six landforms were defined including smooth sand sheet (north and south), rugged vegetated sand sheet, coastal and inland sabkhas, coastal plain, and sand dunes. In general, the Ras Az-Zor is a sandy flat coastal area that is covered mainly with aeolian sand (Al-Hurban, 1996).

Dust storms, locally known as toze, is one of the most common weather phenomena in Kuwait that decreases visibility. Dust particles have diameters of less than $0.8 \mathrm{~mm}$, but a particle diameter of 0.0625 $\mathrm{mm}$ is regarded as the boundary between sand and silt (Bagnold, 1941; and Folk \& Ward, 1957). A subdivision of dust depending on the transportation distance is being made. Dust that is carried a few kilometers to less than $100 \mathrm{~km}$ is generally between $0.005 \mathrm{~mm}$ and $0.05 \mathrm{~mm}$. Material that can be transported over longer distance is generally smaller than $0.02 \mathrm{~mm}$ (Al-Ostad, 1998). This material can remain suspended in the troposphere as aerosol for many days, and sometimes more than a week.

The surface of Kuwait is generally flat or gently undulated desert plain interrupted with low hills, escarpments and depressions. It slopes gradually into the northeast direction, with an average gradient reaching 2m/km (Khalaf \& Al-Ajmi, 1993). In Kuwait, nine soil types are identified by KISR (1999). Despite its small area and climatic uniformity, Kuwait desert can be divided into nine geomorphic provinces that are briefly summarized in Figure (2).

Precipitation in Kuwait is limited to cool season from October to May with an annual average ranging from 115 - $120 \mathrm{~mm} /$ year (Safar, 1984, 1985). Rainfall is extremely variable from year to year and even sometimes from place to place. 


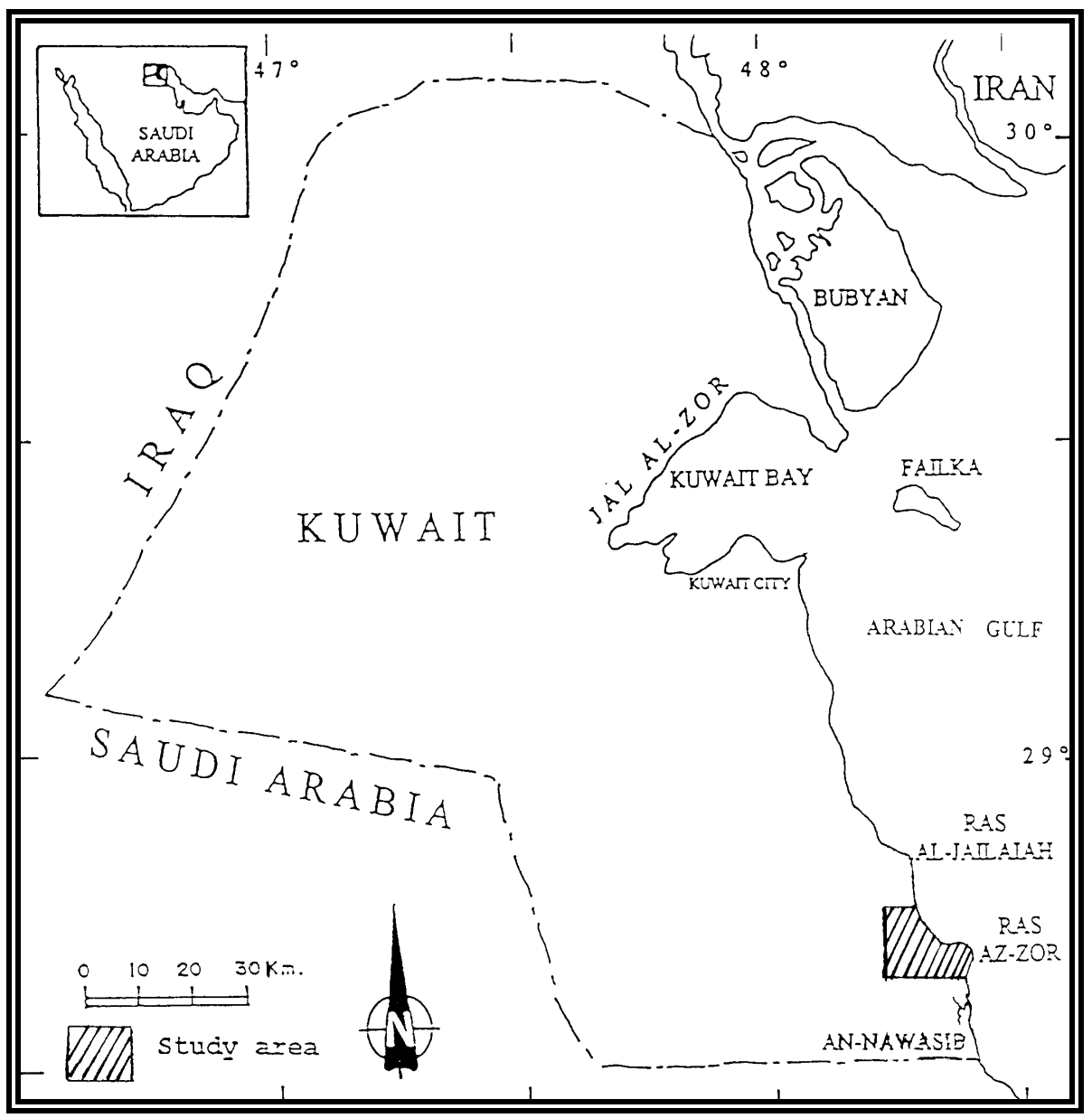

Fig. (1): Location map of the study area.

Winds blow from two directions, the northwest and less extent the southeast. Winds from other directions are less frequent and of shorter duration. Northwesterly wind locally known as Shamal wind, are frequent during summer. In spring (March to May) the wind direction pattern changes where the frequency of south and southeasterly (Monsoon) wind relatively increase (Fig. 3). The northwesterly winds frequently raise dust when they exceed $10 \mathrm{mph}$. 


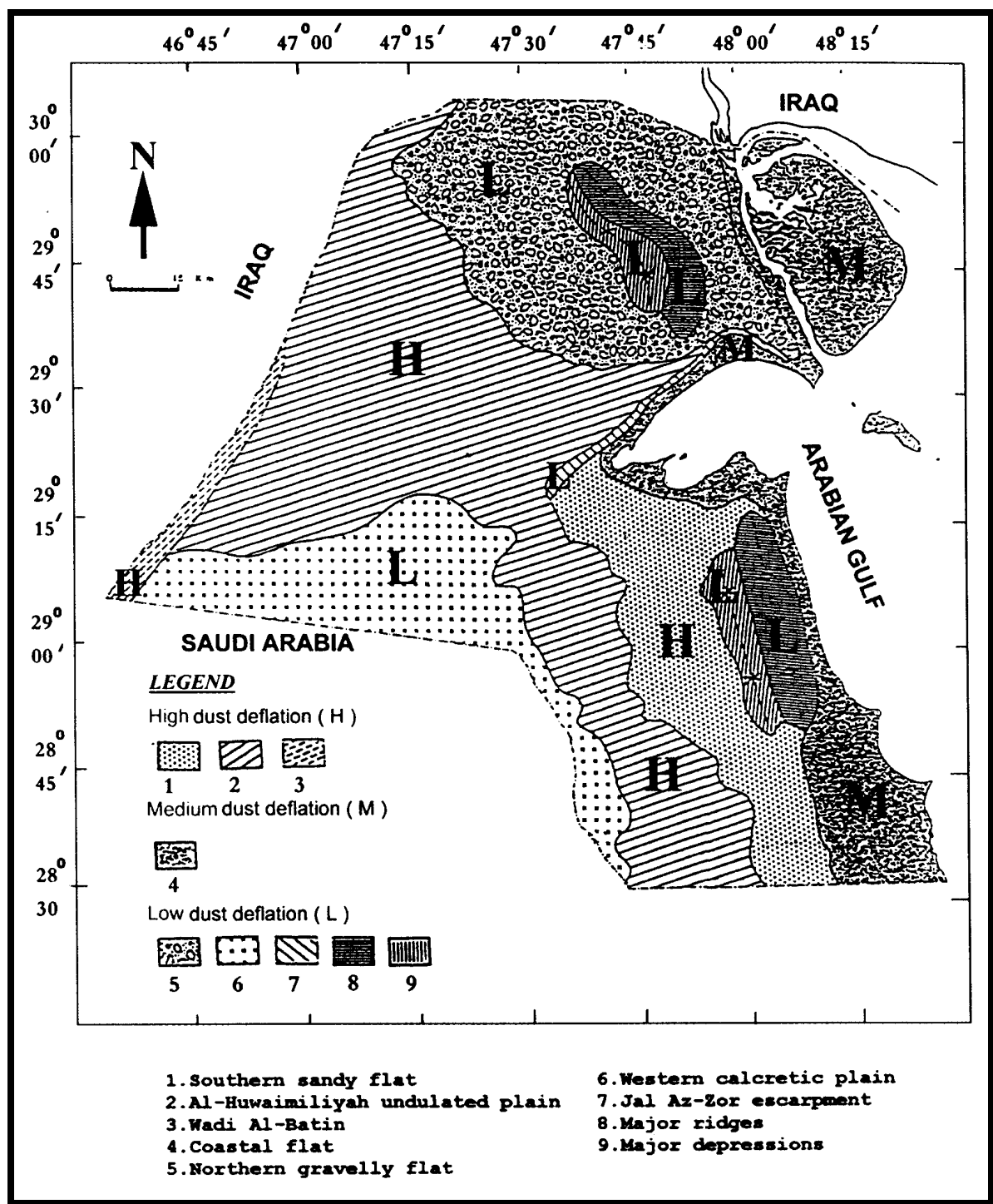

Fig. (2): Simplified geomorphological map and the potential deflation areas in Kuwait. Modified after Khalaf \& Al-Ajmi, 1993.

In general, the country is affected by thunderstorms associated with moving depressions during autumn, winter and spring, but local thunderstorms are frequent in spring and are known as "Sarrayat" (Al- 
Ostad and Ramadan, 1994). They develop during the afternoon or at night and are severe most of the time, because of their rapid development. When this happens, strong, downward, cold-air currents, loose surface dust and sand from the dry desert floor causing a severe dust storm with heavy rain behind.

Vegetation of Kuwait shows a great geographical variation in a very short distance from east to west. Omar et al. (2000) identified eight vegetation units in Kuwait. These are Centropodietum, Cyperetum, Halophyletum, Haloxyletum, panicetum, Rhanterietum, Stipagrostietum and Zygophylletum.

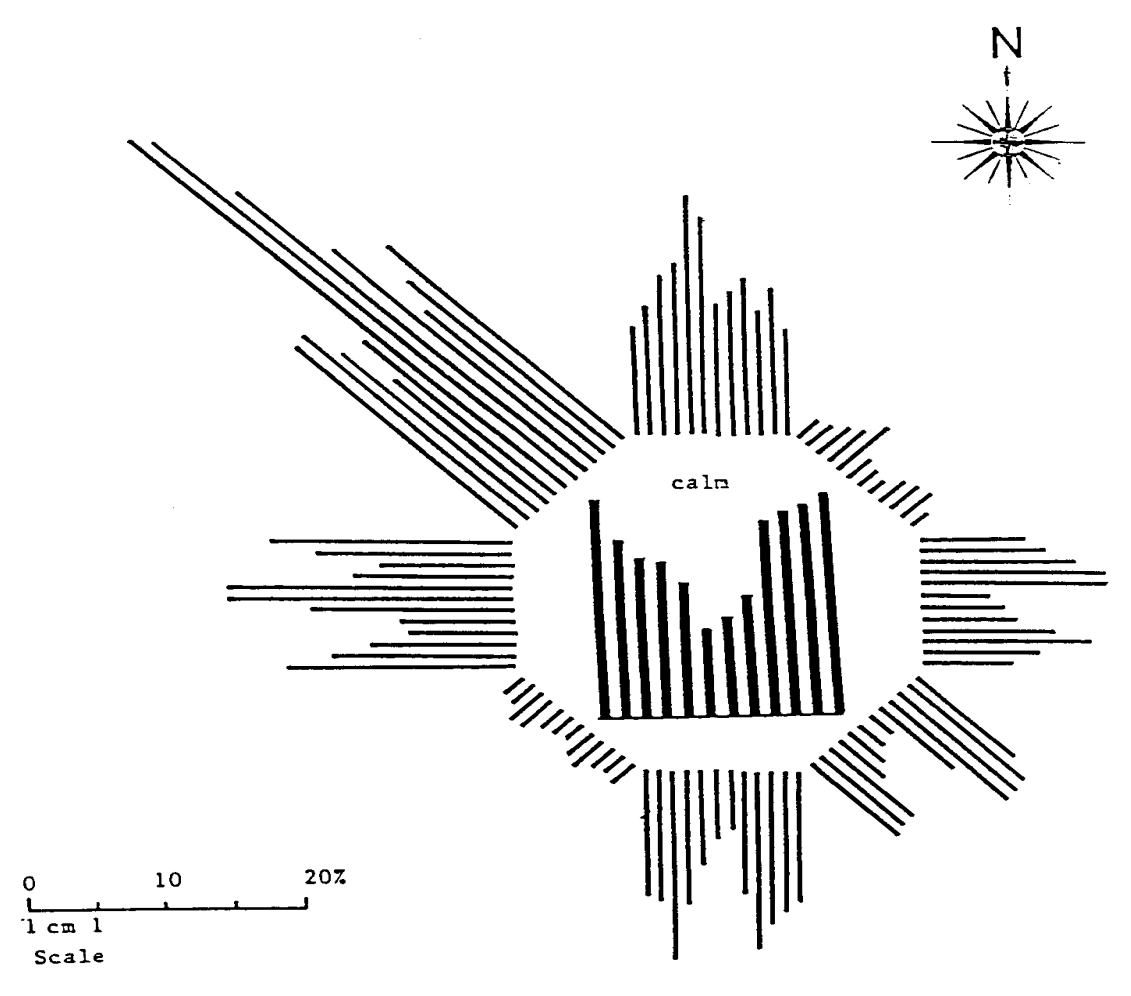

Fig. (3): Average monthly frequency percent of wind from 8 directions. Months are arranged in clockwise direction starting with January. After Khalaf \& Al-Ajmi, 1993. 
Because of the dust problem that is largely facing Kuwait, the aim of the study is to identify the susceptibly of the different landforms to dust deflation. Some of the preliminary factors of study were determined such as the effect of compaction, cement, vegetation cover, moisture content, percentage of fine grains and pebbles, sorting, roundness and percentage of heavy minerals on the different landforms. Thirty-five samples were collected from seven locations (5 from each) (Fig. 4).

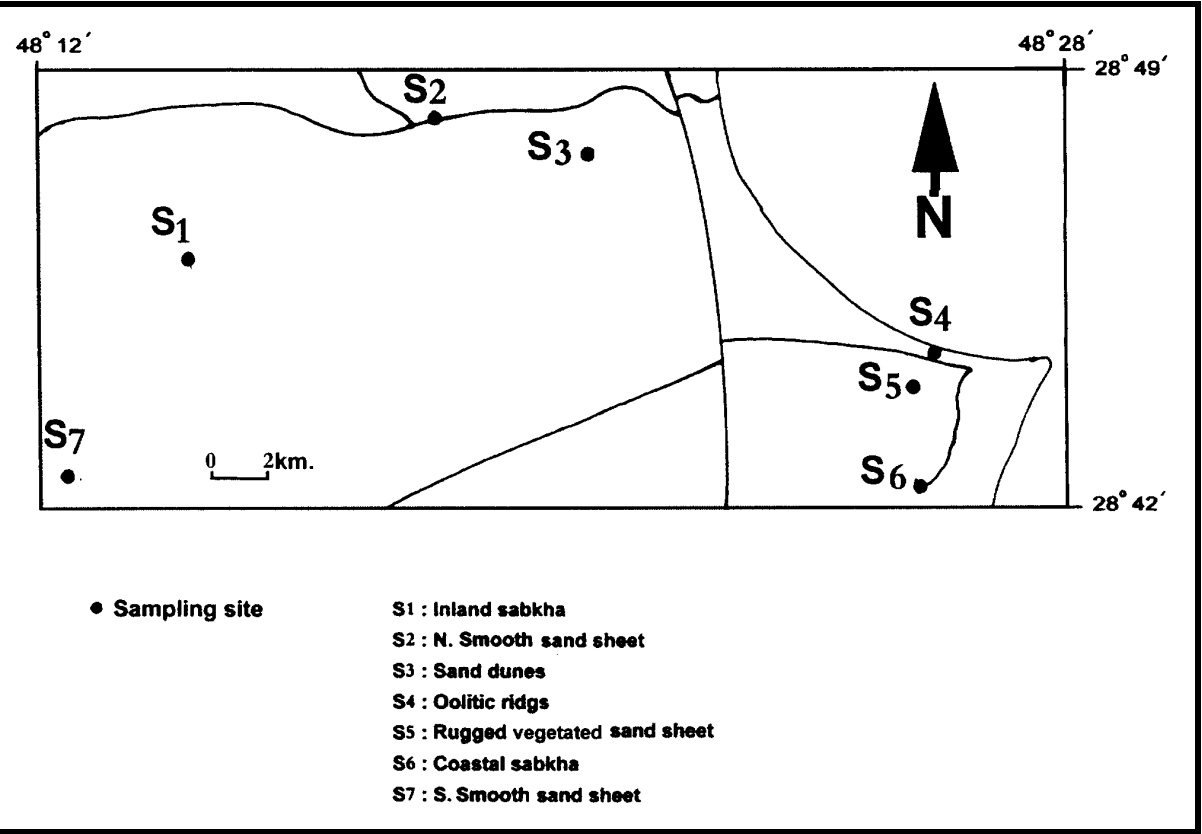

Fig. (4): Sampling map of the study area.

\section{Literature Review:}

Al-Kulaib (1977) discussed the occurrence of dust storms in Kuwait in the various seasons. Safar and Boucaud (1978) studied the relationship between horizontal visibility and wind speed in daytime of the summer season in Kuwait. Safar (1980) has studied the relationship between wind speed and direction and the occurrence of dust in day time in summer to determine the probability of the 
occurrence of dust and the deterioration of visibility within certain ranges of wind speeds.

Khalaf et al. (1984) discussed the types and characters of the recent surface deposits of Kuwait. Aeolian deposits in relation to climatic conditions, soil characters and vegetation cover in Kuwait desert studied by Al-Nakshabandi and El-Robee (1988). Khalaf and Al-Ajmi (1993) investigated the aeolian processes and sand encoarchment problems in Kuwait.

Al-Ostad (1998) applied different methods and techniques to calculate the rate and mass of sand movements by wind in southern area of Kuwait. He concluded that the northwesterly and westerly wind directions transport the highest amount of trapped sand from the surrounding sand sheets.

\section{Methodology:}

Maps of the detailed study area were prepared from aerial photographs which were snapshot during November 1991 with scale of 1:29,000 then reprinted again with a scale of 1:37,000. Spot images of the southern part of Kuwait, which were taken in 1994 with a scale of 1:100,000 also used. The 1995 Kuwait topographic maps (scale 1:50,000) were used after modifying their scale to $1: 37,000$ in order to match the one used in the aerial photographs.

Moisture content within landform samples was measured in the field using the speedy moisture apparatus. Also the moisture content of the collected samples was measured in the laboratory by weighing the sample containers after dryness. Fine sand and pebble percent and sorting were determined using dry sieving analysis. Wet sieving analysis also was used for one sample because it was composed of clay-sized grains and well cemented.

Cementation is indicated visually in the field and in the laboratory to determine the percentage of $\mathrm{FeO}$ and clay-cement using Inductively Coupled Plasma-Atomic Emission Spectrometer (ICP). Power's visual 
compactor, which includes six roundness classes, is used to identify the degree of roundness of each examined quartz grain (Powers, 1953), and then studied by the Scanning Electron Microscope (SEM). The grain-size distribution and the maturity of source sediments are the main factors controlling the roundness of sandy sediments (Khalaf $\&$ Gharib, 1985). Finally, the data of the percentage of heavy minerals were obtained using heavy mineral separation method.

Six major landforms were carefully selected including smooth sand sheet, rugged vegetated sand sheet, coastal and inland sabkhas, oolitic ridges in the coastal plain and sand dunes. The main purpose of collecting samples is to determine the most susceptible landforms to dust deflation. Thirty-five samples (Fig. 4) were collected from seven different locations distributed as follows: two locations for each landform in coastal and inland areas. In each location, five samples were collected from the surface deposits other four were collected each $5 \mathrm{~cm}$ depth $(5,10,15$ and $20 \mathrm{~cm})$ and labelled A, B, C, and D respectively.

The soil compaction was determined by applying Field Density test and measuring moisture content using speedy moisture apparatus. Field density test $\left(\gamma_{d}\right)$ is applied and calculated using the following formula:

$$
\begin{aligned}
& \gamma_{\mathrm{d}}=\frac{\gamma_{\mathrm{ws}}}{1+\mathrm{Wc}_{\mathrm{c}}} \\
& \gamma_{\mathrm{ws}}=\frac{\mathrm{W}_{\mathrm{ws}}}{\mathrm{V} \cdot \text { hole }}
\end{aligned}
$$

Where $\left(\gamma_{d}\right)$ (dry density) is the degree of compaction; $\gamma_{w s}$ is the density of wet sand which is equal to the $\gamma_{t}$, that is the total density; $\mathrm{W}_{\mathrm{c}}$ for the water content, and $\mathrm{Wws}$ is the weight of wet sand; V hole is the volume of the hole. 


$$
\begin{gathered}
\mathrm{V}_{\cdot \text { hole }}=\frac{\mathrm{W}_{\mathrm{hs}}}{\gamma_{\mathrm{s}}} \\
\mathrm{W}_{\mathrm{hs}}=\mathrm{W}_{\mathrm{chs}}-\mathrm{W}_{\mathrm{cs}} \\
\mathrm{W}_{\mathrm{chs}}=\mathrm{W}_{\mathrm{chs}(\mathrm{b})}-\mathrm{W}_{\mathrm{chs}(\mathrm{a})}
\end{gathered}
$$

The weight of the hole sand is Whs; the density of Ottawa sand is $\gamma_{s}$; Wchs is the weight of the cone and the hole sand while Wcs is the weight of the sand fitting the cone.

The water content (Wc) measures by two ways, one in the field using speedy moisture apparatus and the other measured by calculating the difference in weight of soil sample before and after dryness.

Another set of samples (two per one location) has been collected for laboratory moisture determination. They were kept in small metal cans and each one placed in plastic bag and transferred to an icebox to avoid evaporation.

In the laboratory, the samples (A, B, C and D) were used in dry sieving analysis. The data representing the degree of soil sorting was obtained from the cumulative weight percent graphs of the grain size sieving analysis, then calculations were performed using Folk and Ward formula (1957) for the standard deviation (sorting) $(\sigma \phi)$.

The formula used is

$$
\sigma \phi=[(\phi 84-\phi 16)]+[(\phi 95-\phi 5) / 6.6]
$$

Using wet sieving analysis treated the samples collected from the coastal sabkha. In wet sieving analysis, the sieves with mesh numbers 10 and 230 were used with the pan at the bottom. Water is frequently used to wash the samples until all the clay-sized grains retain in the pan. The grain size analysis was performed on A to D sediment samples in order to determine the variation of grain size with depth. 
The wet collected sediments were dried to be treated by sieving analysis to determine the followings:

1. The percentage of the mud-size grains.

2. The percentage of pebbles within each sample.

The reference sediment samples were reused to increase the mudsize quantity required to complete the examination of this fraction. This quantity was diluted in water to separate silt from clays using the centrifuge technique. The percentage of silt and clay then calculated. Roundness was determined to grain fraction including pebbles, and medium sand.

An X-ray diffraction analysis was done on fine sediments to obtain the mineral compositions, and ICP experiment was applied to obtain the average percentage of iron oxides cement in the sediment samples and calculated by using the following formula:

$$
F e=\frac{F e(p p m) \times 100 \mathrm{ml}}{\text { Wt.of sample } \times 10000}
$$

ratio between $\mathrm{Fe}$ and $\mathrm{FeO}=1: 1.286 \quad \mathrm{~K}_{1}$

ratio between $\mathrm{Fe}$ and $\mathrm{Fe}_{2} \mathrm{O}_{3}=1: 1.43 \quad \mathrm{~K}_{2}$

$\% \mathrm{FeO}=\mathrm{Fe} \% \times \mathrm{K}_{1}$

$\% \mathrm{Fe}_{2} \mathrm{O}_{3}=\mathrm{Fe} \% \times \mathrm{K}_{2}$

average $\%$ of $\left(\mathrm{FeO}+\mathrm{Fe}_{2} \mathrm{O}_{3}\right)$ cement $=\left(\mathrm{FeO} \%+\mathrm{Fe}_{2} \mathrm{O}_{3}\right) / 2$

\section{Factors Affecting Dust Deflation:}

The factors affecting the dust deflation can be divided according to their effect into high, medium and low (Table 1). The degree of cement compaction, percentage of fine size material, and moisture content are categorized under the most effective factors on dust deflation. Pebble percent, vegetation cover and sorting lies under the moderate affecting factors on dust deflation. While the degree of roundness of the grains and the percentage of heavy minerals have the least effect on dust deflation. To simplify the result each category of the factors has been rate to indicate its intensity; for instance the highest most affecting will be given the highest rate 60, 40, and 20 . The medium factors given rate of 30,20 , and 10 while 15,10 , and 5 
assigned to the least affecting factors. Table 2 shows the terrain characteristics and their distinguished rates that will be used to determine the ranks for dust deflation. To aid the purpose of the study, sorting standard seven ranks were reduced into three only. Also the same was applied to the roundness ranks.

Table 1. Factors affecting dust deflation.

\begin{tabular}{|c|c|c|}
\hline $\begin{array}{l}\text { Terrain characteristics } \\
\text { A. The highest affecting factors } \\
\text { 1. Cement }\end{array}$ & $0-20 \%$ & Rating \\
\hline i. Clay cement & $>20-40 \%$ & 40 \\
\hline & $>40 \%$ & 20 \\
\hline & $0-0.3 \%$ & 60 \\
\hline ii. Iron oxide cement & $>0.3-0.6 \%$ & 40 \\
\hline & $>0.6 \%$ & 20 \\
\hline & Lack cement & 60 \\
\hline iii. Visual distribution of soil cementation & Slightly cemented & 40 \\
\hline & Well cemented & 20 \\
\hline 2. Compaction & $0.0-1.40 \mathrm{~g} / \mathrm{cc}$ & 60 \\
\hline & $>1.40-1.80 \mathrm{~g} / \mathrm{cc}$ & 40 \\
\hline & $>1.80 \mathrm{~g} / \mathrm{cc}$ & 20 \\
\hline 3. Percentage of fine size material & $0-3 \%$ & 20 \\
\hline & $>3-10 \%$ & 40 \\
\hline & $>10 \%$ & 60 \\
\hline 4. Moisture content & $0-10$ & 60 \\
\hline & $>10-20$ & 40 \\
\hline & $>20$ & 20 \\
\hline B. Moderately affecting factors & & \\
\hline 5. Pebble percent & $0-1 \%$ & 30 \\
\hline & $>1-5 \%$ & 20 \\
\hline & $>5 \%$ & 10 \\
\hline 6. Vegetation cover & Non & 30 \\
\hline & Slightly (desert grass) & 20 \\
\hline & Shrubs & 10 \\
\hline 7. Sorting & Well-sorted & 30 \\
\hline & Moderately-sorted & 20 \\
\hline & Poorly-sorted & 10 \\
\hline C. Factors with least effect & & \\
\hline 8. Roundness & Rounded & 15 \\
\hline & Sub-rounded & 10 \\
\hline & Angular & 5 \\
\hline 9. Percentage of heavy minerals & $0-1.5 \%$ & 15 \\
\hline & $>1.5-5 \%$ & 10 \\
\hline & $>5 \%$ & 5 \\
\hline
\end{tabular}


For the final classification of land units with respect to their susceptibility to dust deflation, the landforms were classified according to the summation of the number or rates of affecting factors (Table 2).

Table 2. Rate of terrain with dust deflation.

\begin{tabular}{|c|l|}
\hline Summation of Rates & Susceptibility to dust deflation \\
\hline $200-329$ & $\begin{array}{l}\text { Not or insignificantly susceptible to dust } \\
\text { deflation (SDD) }\end{array}$ \\
\hline $330-370$ & Slightly susceptible to dust deflation \\
\hline $371-379$ & Moderately SDD \\
\hline $380-390$ & High SDD \\
\hline$>390$ & Extremely to very high SDD \\
\hline
\end{tabular}

\section{Results \& Discussion:}

Based on the results of the field investigations a detailed map showing the distribution of the various terrain types was prepared. The topographic maps of scale 1:50,000, the geologic map of scale 1:250,000 of 1981, and the aerial photographs of scale 1:29,000 of 1991 as bases for the area (Fig. 5). These terrain types include coastal and inland sabkhas, smooth sand sheet, rugged vegetated sand sheet, sand dunes, and oolitic ridges.

An X-ray diffraction of dust particles reveals that the mineral composition is mainly quartz and albite that may be transported from the Arabian Shield (Fig. 6). Within the more dominant minerals are gypsum, dolomite, aragonite and calcite. These most probably originate from local sources especially the coastal area.

From the roundness of sand grains it was found that grains from coastal sabkhas are more rounded in shape than inland ones, which are elongated and irregular in shape (Plate 1). The southern sand sheets grains are more rounded in shape than the northern ones (Plate 1), While most sediments from coastal plain are rounded in shape (Plate $1)$. 


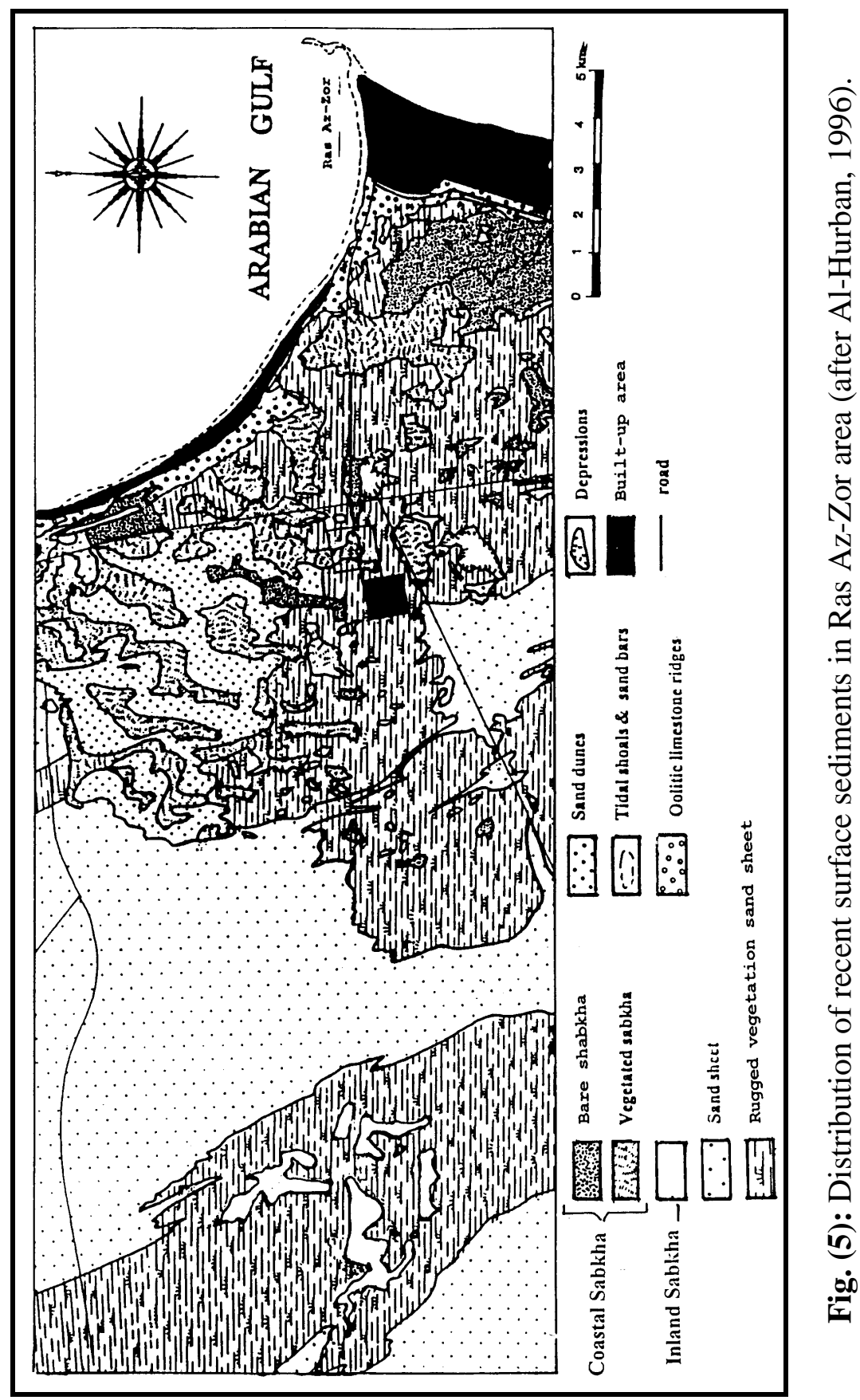

[13] 


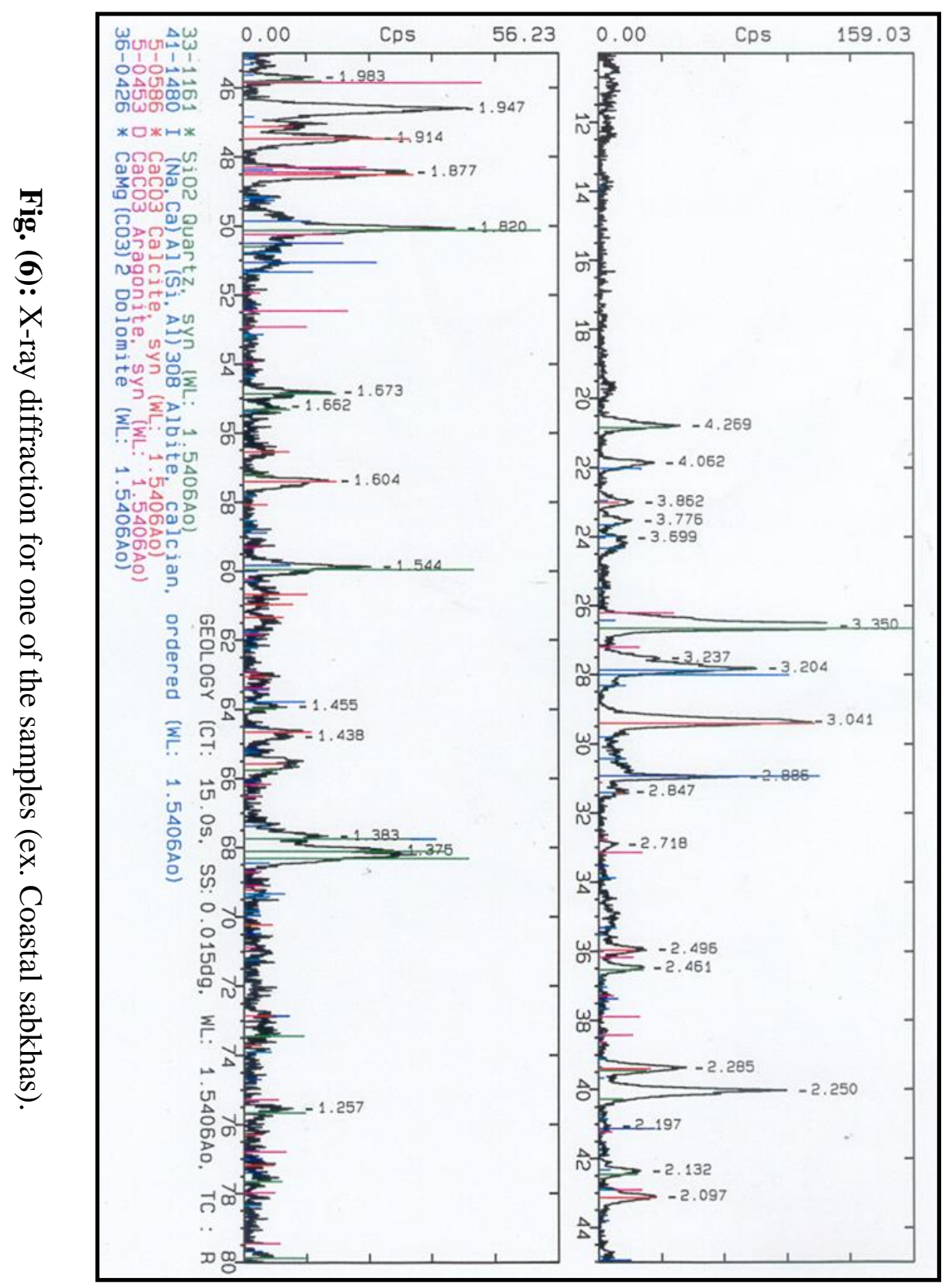




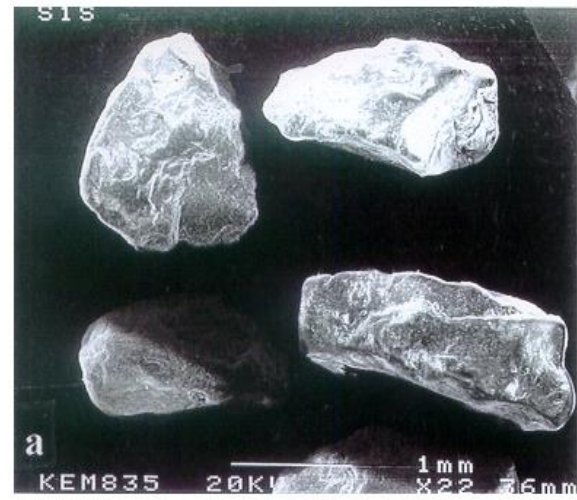

Inland Sabkha $\left(\mathrm{S}_{1}\right)$

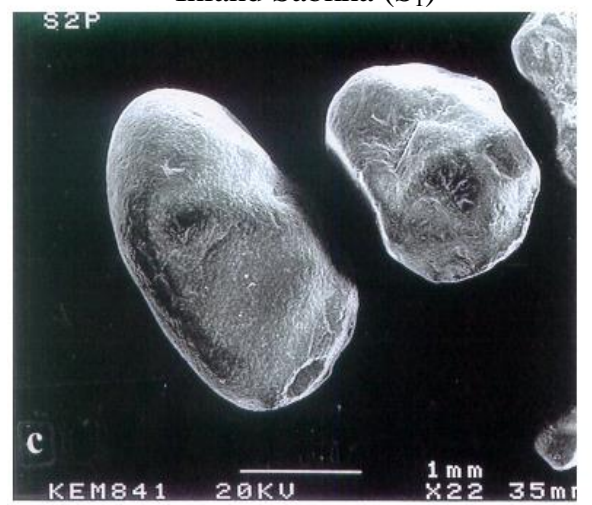

$\mathrm{N}-$ Smooth Sand Sheet $\left(\mathrm{S}_{2}\right)$

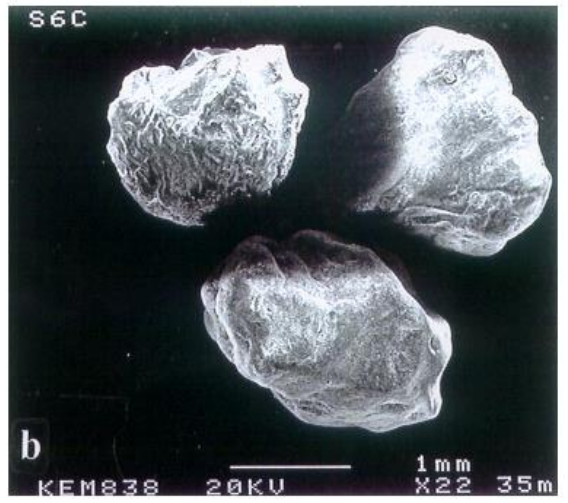

Coastal Sabkha $\left(\mathrm{S}_{6}\right)$

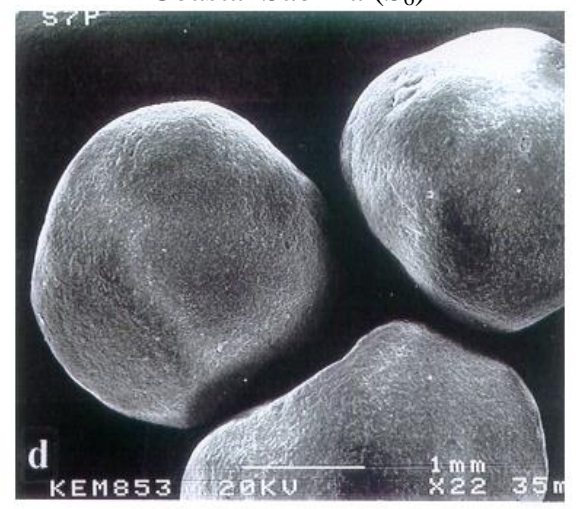

S-Smooth Sand Sheet $\left(\mathrm{S}_{7}\right)$

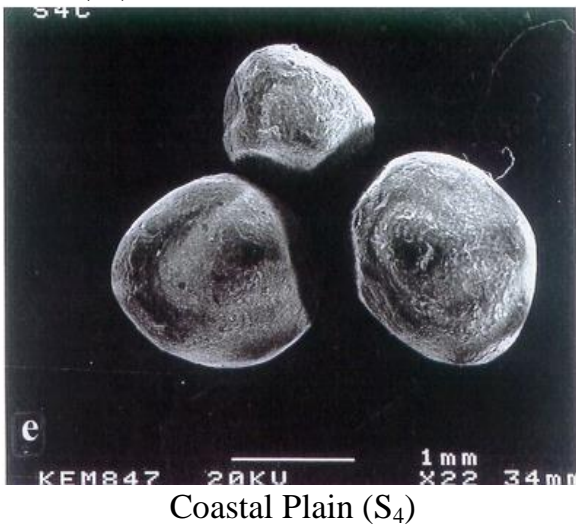

Plate 1 
Vegetation covers being also described in the field. The description reveals the following results:

1. No vegetation is found at all in the sabkha (S1 and S6) area irrespective to land or the coast.

2. Shrubs, small shrubs are found mainly near the coast or the oolitic ridges (S4) and on the vegetated sand sheet (S5).

3. Other landforms are slightly covered with desert grass.

Samples for different landforms (sample A-D) do not show any significant relation regarding the changes in grain size with depth (Fig. 7). No matter whether it is related to the same landform or it is coastal or inland, but this is connected with the history of development and the characteristics of landforms itself.

The results are summarized in table 3 and 4 . Table 3 summarized the different landform experiments while Table 4 shows proposed ranking for each factor and the net result for the susceptibility to deflation.

From table (3) the highest factors affecting the dust deflation such as cementation, compaction, and moisture content, shows that the highest affected terrain is the inland sabkhas, followed by smooth sand sheet, and then sand dunes; while the least affected one is the coastal sabkha because it contains more clay cement, more compacted and with high moisture content.

From the moderate factors affecting the dust deflation such as the percent of pebble, the amount of vegetation cover, and the sorting of grains, it can be noticed that the ones with less percent of pebbles will be more affected such as inland sabkhas, and oolitic ridges. The ones with less vegetation is more affected such as types of sabkhas. The well-sorted terrain is more affected by deflation such as inland sabkha.

From the least factors affecting the dust deflation such as the percent of heavy minerals and roundness of grain, it can be noticed that the inland sabkha is the highest affected one, because it has the lowest percentage of heavy minerals and the more rounded grain, followed by sand sheet, and sand dunes. 

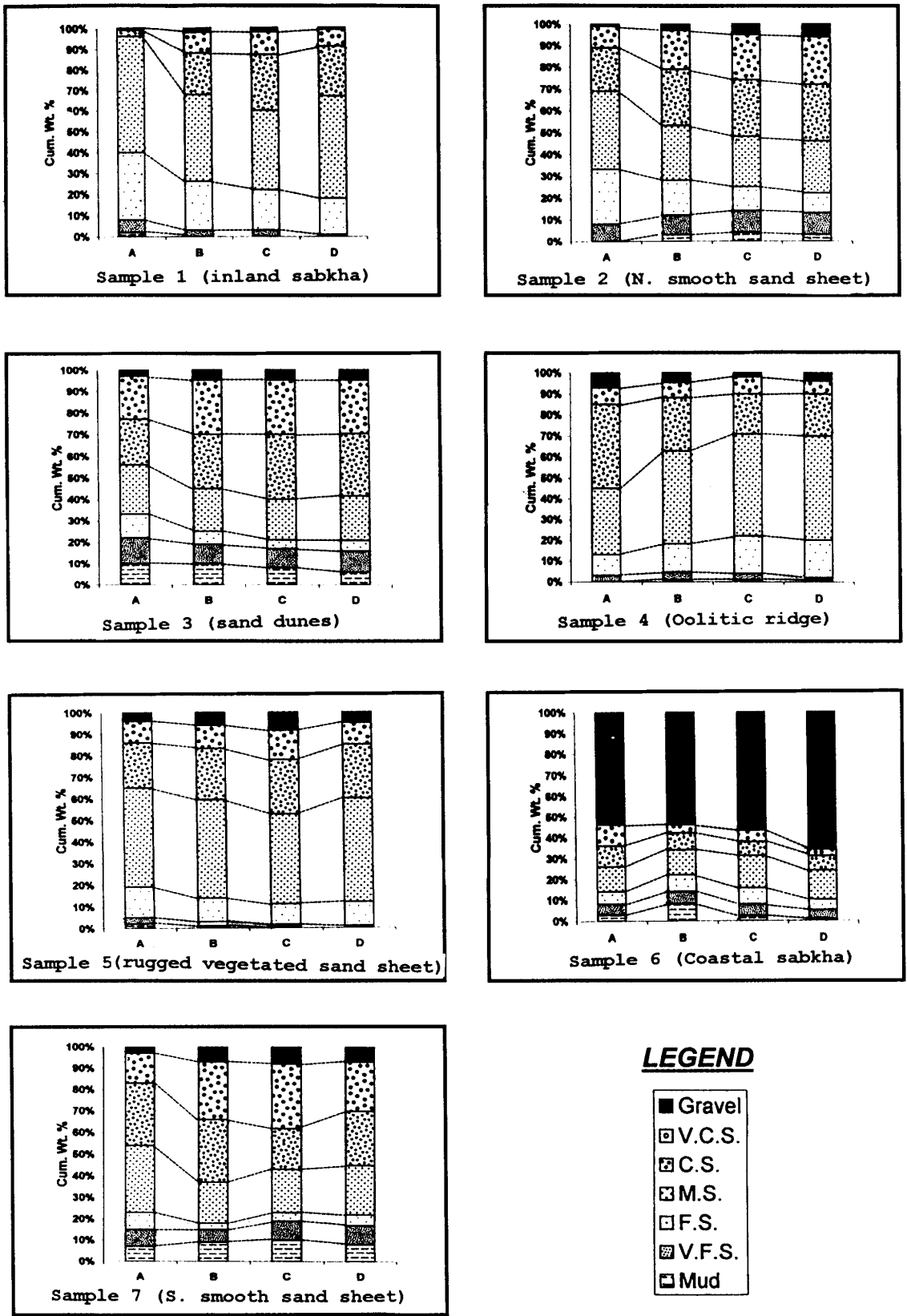

\begin{tabular}{|c|}
\hline 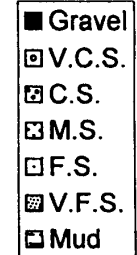 \\
\hline
\end{tabular}

Fig. (7): The changes in grain size with depth in the different landforms. (See Fig. 4 for more details). 
It has been noticed from table 4 that the inland sabkha represents the most susceptible landform for dust deflation though it has negligible percentages of fine material and fairly good moisture content.

Sabkhas are usually characterized by its fine-grained clastic and non-clastic sediment. The clastic sediments mainly derived by wind action, while the non-clastic are composed basically of saline deposits from evaporation processes. As most sabkhas occur in the lowest area of inclosed basin, solid material can be removed from them only by wind. In addition not all sabkha sediment is equally susceptible to deflation. A hard dry crusts sabkhas with a high clay content, such as in coastal sabkha, are very much more resistance to deflation than surface material rich in salt (Coque, 1962). Moreover, the susceptibility of sabkha to dust deflation varies with its moisture content, which is quite variable in area, depth, and season. The effective limits of deflation in sabkha are watertable. When watertable is close to the surface this surface will be wet and less resistance to deflation. This is particularly important datum in sabkha, and that was the reason of the different potentiality of dust deflation in the inland and coastal sabkha.

The coastal plain represented by the oolitic limestone ridges and the coastal vegetated sand sheet are highly affected by dust deflation. Since the area is affected by aeolian coastal activities, two main sources of mud-size sediments are available. The wind transports the mud by suspension, and the wave crumbled the shells, grains and the nearby ridges into smaller grain fractions. A large quantity of dust will be available in that area waiting for good opportunity for its deflation. The difference in potentiality of dust deflation between land and coastal vegetated sand sheet is related mainly to the high quantity of fine material and almost the absence of gravel protective layer at the coast. As the Mother Nature always tends to maintain itself, weathering and erosion processes usually affect the high relief area, where deposition occurs in the basins. For that reason, vegetated sand sheet that is characterized by high relief is highly more susceptible to dust deflation than the smooth sand sheet. 


\begin{tabular}{|c|c|c|c|c|c|c|c|c|c|c|c|c|c|c|}
\hline 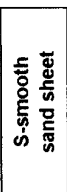 & $\hat{s}$ & $\frac{n}{i n}$ & $\begin{array}{l}\Delta \\
\dot{\sigma} \\
\end{array}$ & 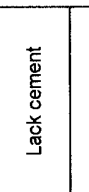 & $\stackrel{\mathbb{\infty}}{\stackrel{\leftrightarrow}{-}}$ & $\stackrel{R}{r}$ & $\stackrel{8}{:}$ & $\underset{\tilde{\sigma}}{\tilde{\sigma}}$ & 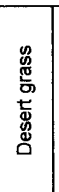 & 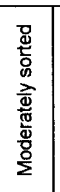 & $\stackrel{8}{-}$ & 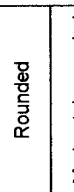 & 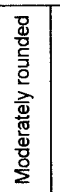 & 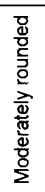 \\
\hline 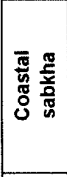 & 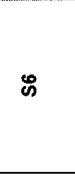 & 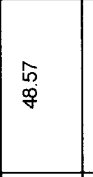 & 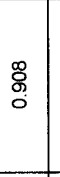 & 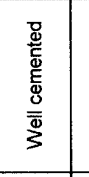 & 邑 & $\begin{array}{l}\infty \\
0 \\
0 \\
0\end{array}$ & ? & $\begin{array}{l}\stackrel{\infty}{\infty} \\
0 \\
0\end{array}$ & 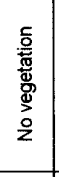 & 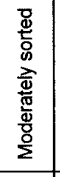 & $\stackrel{8}{-}$ & 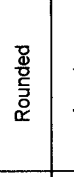 & $\begin{array}{l}\frac{1}{0} \\
\frac{3}{3} \\
\frac{\sigma}{4}\end{array}$ & $\begin{array}{l}\text { 总 } \\
\text { 产 } \\
\text { a }\end{array}$ \\
\hline 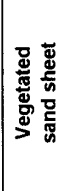 & $\ddot{\infty}$ & \begin{tabular}{|l}
$\infty$ \\
$\stackrel{\infty}{\sim}$ \\
$\tilde{N}$
\end{tabular} & 总 & 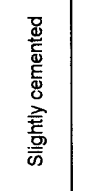 & 葛 & 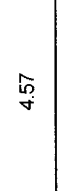 & $\stackrel{9}{R}$ & $\begin{array}{l}\hat{\mathbf{a}} \\
\mathrm{o}\end{array}$ & $\begin{array}{l}\frac{n}{2} \\
\frac{\vec{z}}{5} \\
\frac{5}{5}\end{array}$ & 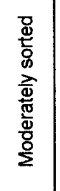 & 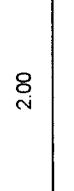 & 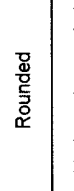 & 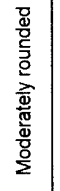 & $\frac{\frac{5}{3}}{\frac{3}{4}}$ \\
\hline 善 & ळ & 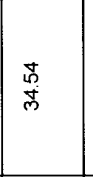 & 尽 & 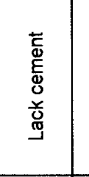 & $\stackrel{\circ}{-}$ & $\overline{\overline{0}}$ & $\stackrel{m}{m}$ & : & 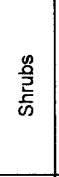 & 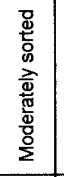 & $\stackrel{ \pm}{\cong}$ & 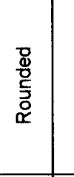 & $\begin{array}{l}\text { 总 } \\
\text { 产 } \\
\text { व. }\end{array}$ & 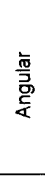 \\
\hline 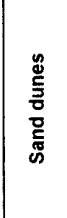 & 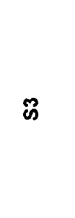 & $\begin{array}{l}\pi \\
6\end{array}$ & $\begin{array}{l}8 \\
8 \\
0\end{array}$ & 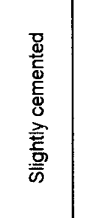 & $\stackrel{0}{\circ}$ & : & $\stackrel{\mathbb{N}}{\mathbb{N}}$ & $\tilde{N}$ & 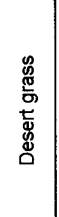 & 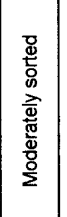 & 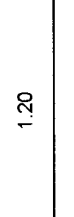 & 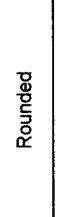 & 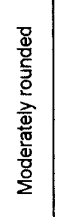 & $\begin{array}{l}\frac{\bar{m}}{\overline{3}} \\
\frac{\bar{z}}{4}\end{array}$ \\
\hline 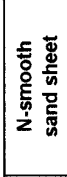 & ก & $\frac{t}{i s}$ & 总 & 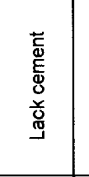 & $\bar{i}$ & $\stackrel{ \pm}{ \pm}$ & 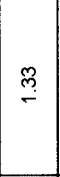 & $\underset{\mathcal{N}}{\mathcal{N}}$ & 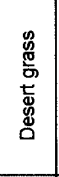 & 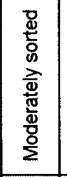 & 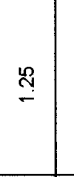 & 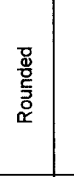 & 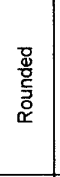 & $\begin{array}{l}\frac{\mathrm{m}}{3} \\
\text { 臬 }\end{array}$ \\
\hline 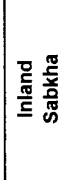 & $\bar{\omega}$ & $: 8$ & 节 & 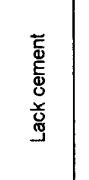 & $\frac{7}{-}$ & $\overline{\bar{o}}$ & $\stackrel{\sim}{\stackrel{N}{m}}$ & 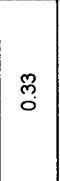 & 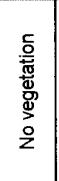 & 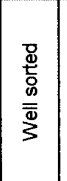 & : & 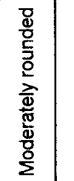 & 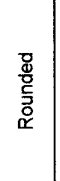 & 高离 \\
\hline & 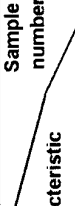 & 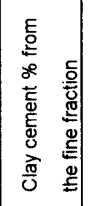 & 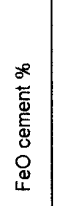 & 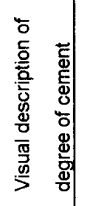 & & 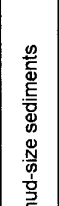 & 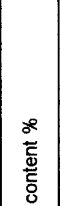 & 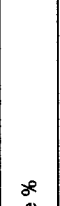 & 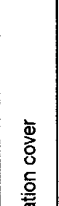 & & 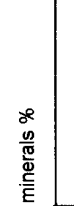 & 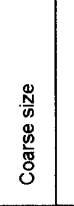 & 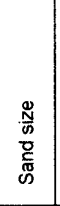 & 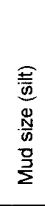 \\
\hline & & \multicolumn{3}{|c|}{ 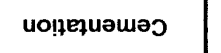 } & & \begin{tabular}{|l|} 
\\
\\
0 \\
\end{tabular} & 离 & 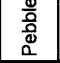 & 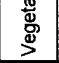 & \begin{tabular}{|l|} 
\\
$\begin{array}{c}0 \\
5 \\
\\
\end{array}$ \\
\end{tabular} & $\mid$ & \multicolumn{3}{|c|}{ ssəupunoy } \\
\hline & & \multicolumn{6}{|c|}{ 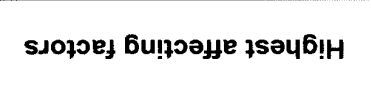 } & \multicolumn{3}{|c|}{ 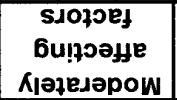 } & \multicolumn{4}{|c|}{ 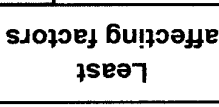 } \\
\hline
\end{tabular}




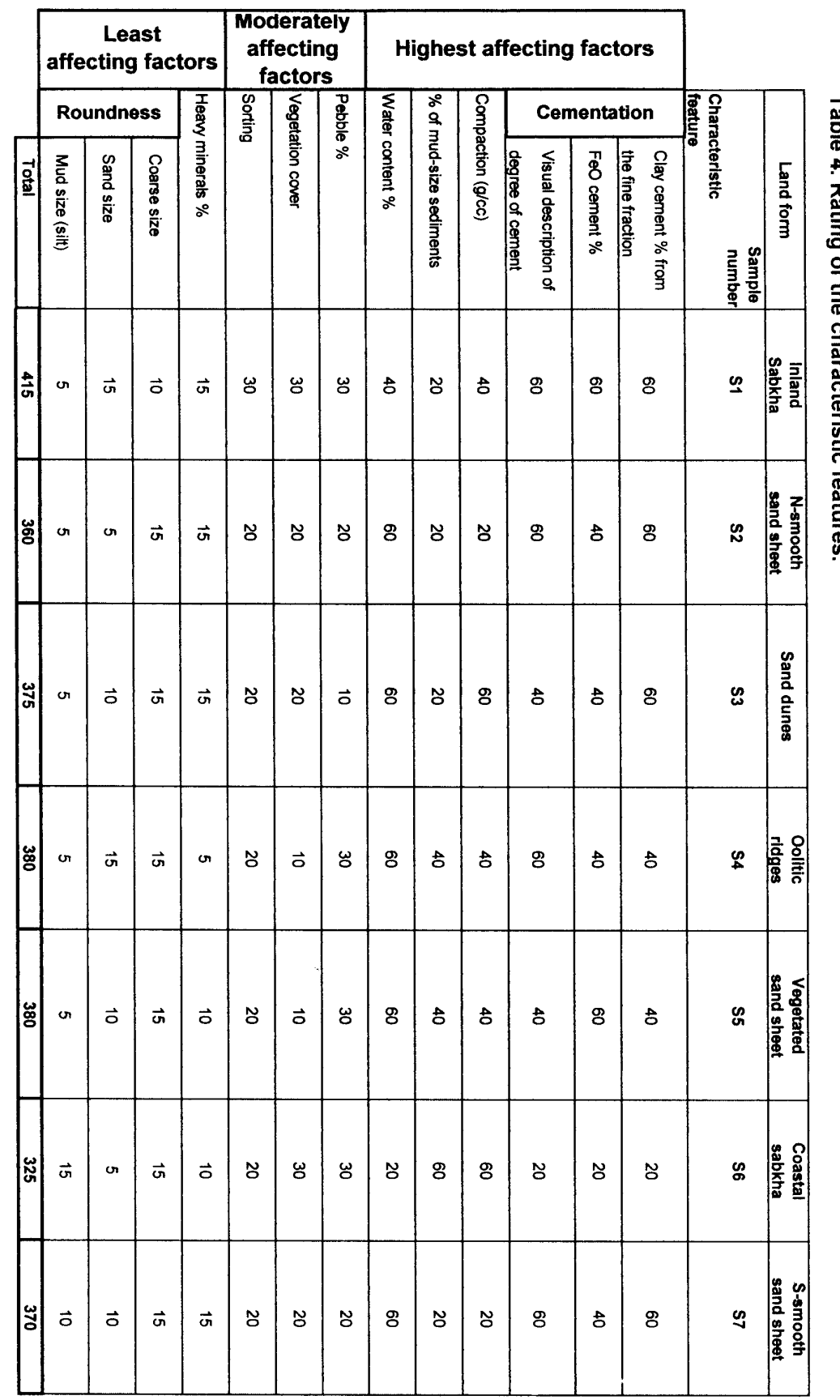


The least susceptible unit for dust deflation is the coastal sabkha. Since it is nearby the beach, watertable is very close to the surface, highly cemented by clay material and protected by hard cover that impedes deflation.

\section{Conclusions:}

Dust deflation is a function of climate, soil characteristics, moisture content, vegetation cover, and land misuse. Landforms respond to these factors in different strength. Thus, these factors are ranked according to their influence degree on dust deflation into three major categories, highly, moderately and least effective. The previous factors being applied to some selected landforms located at Ras AzZor area, southern part of Kuwait, in order to study their potentiality to dust deflation. Inland sabkhas with relatively deep watertable is the most susceptible landform for dust deflation followed by the coastal plain landforms, the vegetated sand sheets, the sand dunes, then the smooth sand sheets. Coastal sabkhas considered as the least unit to dust deflation since the shallow watertable acts as a base level of erosion, and the crust is very hard and well cemented to any grain size.

\section{Acknowledgement:}

Thanks are due to Mr. Mamdouh Abdul-Hameed, Assistant lecturer in the Earth and Environmental Sciences Department- Kuwait University, for his assistant during the fieldwork. Thanks are also due to Mr. Mohammed Sami, senior technician in the same department for his assistance in interpreting the X-ray results.

Grateful thanks are to Mr. Mohammed Rafeeq and Mohammed Sameer, technicians in the Scanning Electron Microscopy (SEM) Unit of Kuwait University for their kind help and assistance. Thanks are due to Mr. Hani Ameen, assistant lecturer in the Faculty of Petroleum and Engineering for providing with the instruments required for the fieldwork. Thanks are due to Mr. Ismail Gharib, assistant lecturer in the Earth and Environmental Sciences Department-Kuwait University for his suggestions during the fieldwork and for reviewing the manuscript. 


\section{References:}

- Al-Hurban A. (1996), Recent surface sediments and landforms of the southern area of Kuwait. PhD thesis, University of Birmingham, England.

- Al-Kulaib A. A. (1977), Weather and climate of Kuwait, Unpublished Report, Climatological Section, Meteorological Department, Directorate General of Civil Aviation, Kuwait International Airport, 82 pp.

- Al-Nakshabandi G. A., and El-Robee, F. T., (1988), Aeolian deposits in relation to climatic conditions, soil characteristics and vegetation cover in Kuwait desert, Journal of Arid Environments, 15: 229-243.

- Al-OstadA., and Ramadan E., (1994), A study of local thunderstorms (Sarrayat) in Kuwait. Journal of Meteorology. Vol. 19, no. 189,p. 150-155.

- Al-Ostad A. (1998), Aeolian sand and dust transport in southern Kuwait and relationships with climate, Ph.D. thesis, University of Birmingham, England.

- Bagnold R. A. (1941), The physics of blown sand and desert dunes, Chapman \& Hall, London, $265 \mathrm{pp}$.

- Coque R. (1962), La Tunisie pre'-Saharienne, e'tude g'eomrphologique, Colin, Paris.

- Folk R. L., and Ward W., (1957), Brazos river bar, a study in the significance of grain size parameters, Journal Sediment. Petrol., 27, p. 3-27.

- Gunatilaka A. (1986), Kuwait and Northern Arabian Gulf: A study in Quaternary sedimentation. Episodes, vol. 9, p. 223-231.

- Gunatilaka A., and Mwango S., (1987), Continental sabkha pans and associated nebkhas in southern Kuwait, Arabian Gulf. From Frostick, L.; and I. Reid (eds), (1987), Desert sediments: Ancient \& modern, Geological Society Special publication No. 35, p. 187-203.

- Khalaf F. I., Gharib I. M., and Al-Hashash M. Z., (1984), Types and characteristics of the recent surface deposits of Kuwait, Arabian Gulf, Journal of Arid Environments, 7: 9-33.

- Khalaf F.I., and Gharib I.M., (1985), Roundness parameters of quartz grains of recent Aeolian sand deposits in Kuwait; Sedimentary Geology, 45, 147-158.

- Khalaf F. I., and Al-Ajmi D., (1993), Aeolian processes and sand encroachment problems in Kuwait, Geomorphology, 6: 111-134.

- KISR (1999), Soil Survey for the State of Kuwait, Vol. 1: Executive Summary. AACM International, Adelaide, Australia. ISBN 095770 030x.

- Omar S.; Misak R.; King P.; Shabbir A.; Abo Rizq H.; Greanish G.; and Roy W., (2000), Mapping the vegetation of Kuwait Through Reconnaissance Soil Survey. Journal of Arid Environment. p. 341-355, Vol. 48, No. 3.

- Powers M.C. (1953), A new roundness scale for sedimentary particles. J. Sediment. Petrol., 23, 117-119.

- Safar M. I., and Boucaud A. (1978), Visibility and wind in daytime early summer dust in Kuwait, Meteorological Department, Kuwait, 3 pp.

- Safar M. I. (1980), Frequency of dust in daytime summer in Kuwait, Climatological Section, Meteorological Department, Directorate of Civil Aviation, Kuwait International Airport, Kuwait, 107 pp.

- Safar M. I. (1984), Climate and life. General of Civil Aviation Meteorological Department. Kuwait. (In Arabic).

- Safar M. I. (1985), Dust and duststorms in Kuwait. Directorate General of Civil Aviation Meteorological Department. $1^{\text {st }}$ ed., Kuwait, 212 p. 